ISSN: $2637-4676$

\title{
Brackish Water Desalination Using Solar Desalination Pannel
}

\author{
Muhammad Arshad Ullah ${ }^{1 *}$, Arshad Ali $^{1}$, Muhammad Aslam $^{1}$ and Khizar Hayat khan ${ }^{2}$ \\ ${ }^{1}$ Land Resources Research Institute, National Agricultural Research Centre, Pakistan \\ ${ }^{2}$ Department of Soil Science, Agricultural Sciences and Technology, Pakistan
}

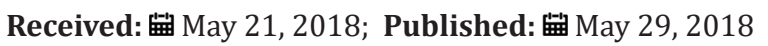

*Corresponding author: Muhammad Arshad Ullah, Land Resources Research Institute, National Agricultural Research Centre, Pakistan

\begin{abstract}
The origin and continuation of mankind is based on water. Water is one of the most abundant resources on earth, covering three-fourths of the planet's surface. Water is one of the earth's most abundant resources, covering about three-quarters of the planet's surface. The reason for this apparent contradiction is, of course, that - $97.5 \%$ of the earth's water is salt water in the oceans and only $2.5 \%$ is fresh water in ground water, lakes and rivers and this supplies most human and animal needs. It would be feasible to address the water-shortage problem with seawater desalination; however, the separation of salts from seawater requires large amounts of energy which, when produced from fossil fuels, can cause harm to the environment. Therefore, there is a need to employ environmentally-friendly energy sources in order to desalinate seawater. Solar distillation systems are increasingly attractive in the areas suffering from shortages of fresh water but where solar energy is plentiful and where operational and maintenance costs are low.
\end{abstract}

\section{Introduction}

Water is essential for life. Many countries around the world, especially developing countries and countries in the Middle East region, suffer from a shortage of fresh water. The United Nations (UN) Environment Programme stated that one-third of the world's population lives in countries with insufficient freshwater to support the population [1]. Consequently, drinking water of acceptable quality has become a scarce commodity. The total global water reserves are_1.4 billion $\mathrm{km}^{3}$, of which around $97.5 \%$ is in the oceans and the remaining $2.5 \%$ is fresh water present in the atmosphere, ice, mountains and ground water. Of the total, only _ $0.014 \%$ is directly available for human beings and other organisms [2]. Thus, tremendous efforts are now required to make available new water resources in order to reduce the water deficit in countries which have shortages [3]. According to World Health Organization (WHO) guidelines, the permissible limit of salinity in drinking water is $500 \mathrm{ppm}$ and for special cases up to $1000 \mathrm{ppm}$ [4]. Most of the water available on the earth has a salinity up to $10000 \mathrm{ppm}$ and seawater normally has salinity in the range of $35000-45000 \mathrm{ppm}$ in the form of total dissolved salts [5]. Desalination is a process in

which saline water is separated into two parts, one that has a low concentration of dissolved salts, which is called fresh water, and the other which has a much higher concentration of dissolved salts than the original feed water, which is usually referred to as brine concentrate [6]. The desalination of seawater has become one of the most important commercial processes to provide fresh water for many communities and industrial sectors which play a crucial role in socioeconomic development in a number of developing countries, especially in Africa and some countries in the Middle East region, which suffer from a scarcity of fresh water.

There is extensive R\&D activity, especially in the field of renewable energy technologies, to find new and feasible methods to produce drinking water $[7,8]$. Currently, there are more than 7500 desalination plants in operation worldwide producing several billion gallons of water per day. Fifty-seven per cent are in the Middle East [9] where large-scale conventional heat and power plants are among the region's most important commercial processes, they play a crucial role in providing fresh water for many communal and industrial sectors, especially in areas with a high density of 
population. However, since they are operated with fossil fuel, they are becoming very expensive to run and the environmental pollution they produce is increasingly recognized as very harmful to the globe. Moreover, such plants are not economically viable in remote areas, even near a coast where seawater is abundant. Many such areas often also experience a shortage of fossil fuels and an inadequate electricity supply. The development of compact, smallscale systems for water desalination is imperative for the population in such areas $[7,8]$. Thermal solar energy water desalination is known to be a viable method of producing fresh water from saline water [2] in remote locations; conventional basin solar stills with a relatively large footprint are an example of such simple technology. And using a clean natural energy resource in water desalination processes will significantly reduce the pollution that causes global warming. This article aims to present a review of the published literature on the various desalination technologies and their advantages and disadvantages in addition to their economics.

Water and energy are two inseparable commodities that govern the lives of humanity and promote civilization. The history of mankind proves that water and civilization are two inseparable entities. This is proved by the fact that all great civilizations were developed and flourished near large sources of water. Rivers, seas, oases, and oceans have attracted mankind to their coasts because water is the source of life. History proves the importance of water in the sustainability of life and the development of civilization. Maybe the most significant example of this influence is the Nile River in Egypt. The river provided water for irrigation and mud full of nutrients. Ancient Egyptian engineers were able to master the river water and Egypt, as an agricultural nation, became the main wheat exporting country in the whole Mediterranean Basin [10]. Energy is as important as water for the development of good standards of life because it is the force that puts in operation all human activities. Water is also itself a power generating force. The first confirmed attempts to harness waterpower occurred more than 2000 years ago in which time the energy gained was mainly used to grind grain [11]. The Greeks were the first to express philosophical ideas about the nature of water and energy. Thales of Militus (640-546BC), one of the seven wise men of antiquity wrote about water $[12,13]$ that it is fertile and moulded (can take the shape of its container). The same philosopher said that seawater is the immense sea that surrounds the earth, which is the primary mother of all life. Later on, Embedokles (495-435BC) developed the theory of the elements [12] describing that the world consists of four primary elements: fire, air, water and earth. These with today's knowledge may be translated to: energy, atmosphere, water and soil, which are the four basic constituents that affect the quality of our lives [14].

Aristotle (384-322), who is one of the greatest philosophers and scientists of antiquity, described in a surprisingly correct way the origin and properties of natural, brackish and seawater. He wrote for the water cycle in nature [15]: "Now the sun moving, as it does, sets up processes of change and becoming and decay, and by its agency the finest and sweetest water is every day carried out and is dissolved into vapor and rises to the upper regions, where it is condensed again by the cold and so returns to the earth. This, as we have said before, is the regular cycle of nature." Even today no better explanation is given for the water cycle in nature. Really, the water cycle is a huge solar energy open distiller in a perpetual operational cycle. For the seawater Aristotle wrote [16]: "Salt water when it turns into vapor becomes sweet, and the vapor does not form salt water when it condenses again. This is known by experiment."Water demand and consumption.

\section{Materials and Methods}

The following are the description of solar powered water desalination system AROCELL solar water purifies Australian technology. It only use sun energy, there are no moving parts, no electronics. It is robust and easy to setup, low maintenance and very low in operating cost because the water purifier only need solar energy. The feed water is supplied by gravity or pressure pump CAROCELL direct solar powered desalination technology, working at ambient temperature, heats the input water causing vapors condensation change precluding all bacteria and pathogens, therefore eliminating all water borne diseases Exposure to ultra violet light and extreme heat from solar energy through the advanced composite panels enhances the germ killing process. CAROCELL's increased efficiency $(65 \%$ with peak efficiencies above $80 \%$ ) over other solar distillation products $(30-40 \%)$ is a combination of the proprietary materials used to dramatically increase the temperature of the feed water on the solar collector which enhances the evaporation/condensation processes inside the panel. Additionally, this sophisticated geometrical design has easy maintenance, optimum performance and a self-controlling natural convection loop enabling widely superior energy recovery (Figure 1). Under this study 04 solar desalination units were installed at National Agricultural Research Centre, Islamabad, Pakistan to check the efficiency of cleaning the brackish water through desalination solar techniques. Further the discharging volume of cleaning water was also determined during 09am to 4pm in the month of February, 2014. 


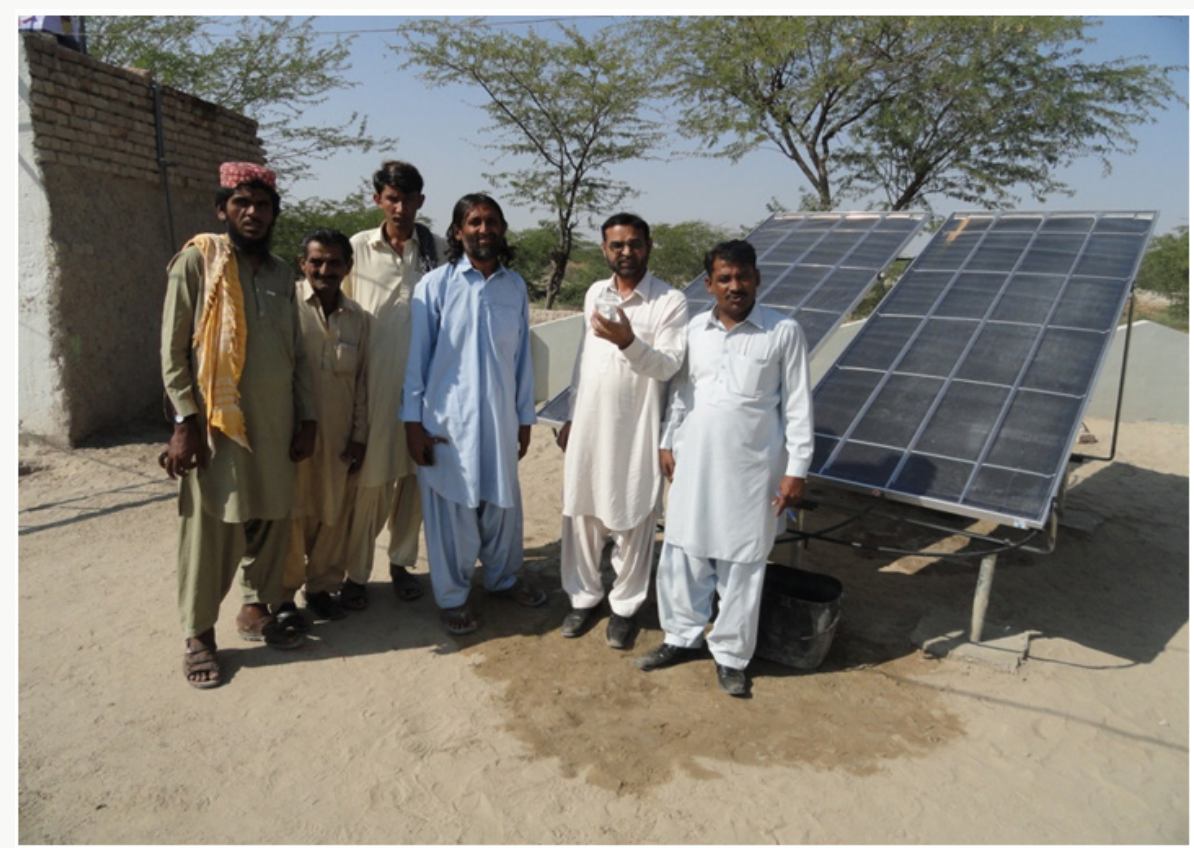

Figure 1: Train the farmers for operation and maintenance of solar desalination system.

\section{Results and Discussions}

Approximately 70\% underground water is brackish. This water is unfit for drinking. The removal of excess salts from brackish water is the utmost requisite for the supply of drinkable water at the remote areas having dense saline water. Water quality is the main issues to save the whole humanity from epidemic diseases. Clean drinkable water is the basic right of the whole world. So this experiment was launched at National Agricultural Research Centre, Islamabad, Pakistan. Electrical conductivity is the main criteria to evaluate the water fitness for drinking purpose. Data presented in Table 1 showed the performance of desalinization solar units installed. Brackish water having different ECw levels under various sunlight temperatures at National Agricultural Research Centre, Islamabad, Pakistan removed the toxic salts through solar desalinization technique and reduced it from 0.01 to $0.11 \mathrm{dSm}-1$. Water having so minute salts is fit for drinking purpose. Utilization of sunlight for the reclamation of brackish water through solar desalinization is the friendly environment, most economical and easily installed with local training. Maintenance cost of these solar units is also very minute.

Table 1: Effect of solar desalination on cleaning of brackish water at NARC, Islamabad, Pakistan.

\begin{tabular}{|c|c|c|c|c|c|c|c|c|}
\hline \multirow{2}{*}{ Time } & \multirow{2}{*}{ Date } & \multicolumn{2}{|c|}{ Temperature ( $\mathrm{C} 0$ ) } & \multicolumn{2}{|c|}{ Discharge(liters) } & \multicolumn{3}{|c|}{$\mathrm{ECe}(\mathrm{dSm}-1)$} \\
\hline & & Min. & Max. & Clean water & Drain water & $\begin{array}{c}\text { Brackish } \\
\text { water }\end{array}$ & Clean Water & Drain Water \\
\hline \multirow[t]{11}{*}{ 09-16PST } & $11-02-2014$ & 7 & 18 & 13.1 & 26 & 1.07 & 0.01 & 0.61 \\
\hline & $12-02-2014$ & 7 & 18 & 14 & 30.6 & 0.73 & 0.02 & 0.66 \\
\hline & $13-02-2014$ & 5 & 21 & 13.4 & 31.2 & 0.85 & 0.01 & 0.49 \\
\hline & $14-02-2014$ & 7 & 17 & 12 & 37.3 & 4.83 & 0.03 & 0.62 \\
\hline & $15-02-2014$ & 7 & 18 & 13.5 & 44.1 & 6.85 & 0.09 & 0.69 \\
\hline & $16-02-2014$ & 5 & 17 & 11.3 & 43 & 6.42 & 0.08 & 6.77 \\
\hline & $17-02-2014$ & 6 & 21 & 13.5 & 37.6 & 0.76 & 0.02 & 0.78 \\
\hline & $18-02-2014$ & 10 & 22 & 15.9 & 35.7 & 10.57 & 0.05 & 10.57 \\
\hline & $19-02-2014$ & 9 & 19 & 14.6 & 28.8 & 13.94 & 0.07 & 17.25 \\
\hline & $20-02-2014$ & 9 & 20 & 14.6 & 36.9 & 19.1 & 0.09 & 19.1 \\
\hline & 21-02-2014 & 9 & 18 & 13.7 & 36.7 & 15.91 & 0.08 & 17.21 \\
\hline
\end{tabular}




\begin{tabular}{|l|l|l|l|l|l|l|l|l|}
\hline & $22-02-2014$ & 7 & 14 & 10.8 & 26.9 & 1.52 & 0.1 & 1.78 \\
\hline & $23-02-2014$ & 8 & 21 & 14.2 & 46.2 & 5.67 & 0.11 & 1.72 \\
\hline & $24-02-2014$ & 9 & 24 & 16.8 & 30.4 & 0.57 & 0.04 & 0.66 \\
\hline & $25-02-2014$ & 11 & 21 & 16.7 & 37.1 & 0.68 & 0.05 & 0.77 \\
\hline & $26-02-2014$ & 11 & 21 & 16.1 & 38.2 & 0.59 & 0.67 & 0.56 \\
\hline
\end{tabular}

The use of solar irradiation for treatment of chemically and biologically contaminated water is not a new trend [17-23]. Pure water is the basic necessary for all living organism. Now days, the availability of clean water resource is a major issue for mankind. A lack of infrastructure for water storage and distribution is also a factor in the developing world. More than $71 \%$ of the earth surface is covered with the water, but only $1 \%$ clean drinkable water is available with the international standards [24]. The purification of brackish water into drinkable water depends upon the intake saline water capacity of each desalinization solar unit. Data indicated in Table 1 showed that the discharge volume of cleaning water was increasing as well as the temperature of the sunlight hours increasing. Solar radiation removes a wide range of organic chemicals and pathogenic organisms by direct exposure, is relatively economical, and avoids cohort of harmful byproducts of chemically driven technologies [17]. More prominently, the economics of the process are approximately capacity self-reliant [25].

\section{References}

1. (2008) United Nations Environment Programme.

2. Al Kharabsheh S, Yogi Goswami D (2003) Analysis of an innovative water desalination system using low-grade solar heat. Desalination 156(1-3): 323-332.

3. Colombo D, De Gerloni M, Reali M (1999) An energy-efficient submarine desalination plant. Desalination 122(2-3): 171-176.

4. WHO/EU (2007) Drinking water standards comparative table, Water treatment \&Air purification and other supporting information.

5. Tiwari GN, Singh HN, Tripathi R (2003) Present status of solar distillation. Solar Energy 75(5): 367-373.

6. Buros OK (2000) The ABCs of Desalting, $2^{\text {nd }}$ edn. ASIN: B0006S2DHY. International Desalination Association.

7. Buros OK (1999) The ABCs of Desalting. International Desalination Association.

8. Gleick, Peter H (1999) The World's Water: The Biennial Report of Fresh Water Resources. Island Press.

9. WDI (2008) Water Desalination International: Introduction. Published by WDI.

10. Delyannis E (2003) Historic background of desalination and renewable energies. Solar Energy 75(5): 357-366.
11. Major JK (1990) Water wind and animal power. In: McNeil J, editor. An encyclopaedia of the history of technology. Great Britain, Bungay: Rutledge, R Clay Ltd pp. 229-270.

12. Delyannis A (1960) Introduction to chemical technology. History of chemistry and technology (in Greek). Athens, 410 (chapter 1).

13. Al Kharabsheh S (2003) Theoretical and experimental analysis of water desalination system using low grade solar heat. PhD dissertation. University of Florida, Berthelot M. In: Steinheil Georges, editor (2001) Collection des Anciens Alchemists Greecs (Collections of the Ancient Greek Alchemists), Paris, France.

14. Delyannis E, Belessiotis V (2000) The history of renewable energies for water desalination. Desalination 128(2): 147-59.

15. Meteorological (1962) Cambridge, MA: Harvard University Press; p. 127. (Book I (Chapter 91)).

16. The Works of Aristotle (1956) In: Encyclopedia Britannica, 1: Book II, 354(25) and 358(15): 464.

17. Calkins J, JD Buckles, JR Moeller (1976) The role of solar ultraviolet radiation in natural water purification. Photochem. Photobiol 24(1): 4957.

18. Conroy RM, M Elmore Meegan, T Joyce, KG McGuigan, J Barnes (1996) Solar disinfection of drinking water and diarrhoea in Maasai children: a controlled field trial. Lancet 348(9043): 1695-1697.

19. Davies Colley RJ, RG Bell, AM Donnison (1994) Sunlight inactivation of enterococci and fecal coliforms in sewage effluent diluted in seawater. Appl Environ Microbiol 60: 2049-2058.

20. Malik MAS, GN Tiwari, A Kumar, MS Sodha (1982) Solar distillation: a practical study of a wide range of stills and their optimum design, construction and performance. Pergamon Press, Oxford, United Kingdom.

21. Safapour N, RH Metcalf (1999) Enhancement of solar water pasteurization with reflectors. Appl Environ Microbiol 65(2): 859-861.

22. Sinton LW, RK Finlay, PA Lynch (1999) Sunlight inactivation of fecal bacteriophages and bacteria in sewage-polluted seawater. Appl. Environ. Microbiol 65: 3605-3613

23. Sinton LW, CH Hall, PA Lynch, RJ Davies Colley (2002) Sunlight inactivation of fecal indicator bacteria and bacteriophages from waste stabilization pond effluent in fresh and saline waters. Appl Environ Microbiol 68: 1122-1131.

24. Dev Rahul, Tiwari GN (2009) Characteristic equation of a passive solar still. 245(1-3): 246-265.

25. Gloyna EF (1971) Waste stabilization ponds. World Health Organization, Geneva, Switzerland. 


\section{(c) (i) This work is licensed under Creative Commons Attribution 4.0 License}

Submit Your Article Click Here: Submit Artic

DOI: 10.32474/CIACR.2018.03.000152

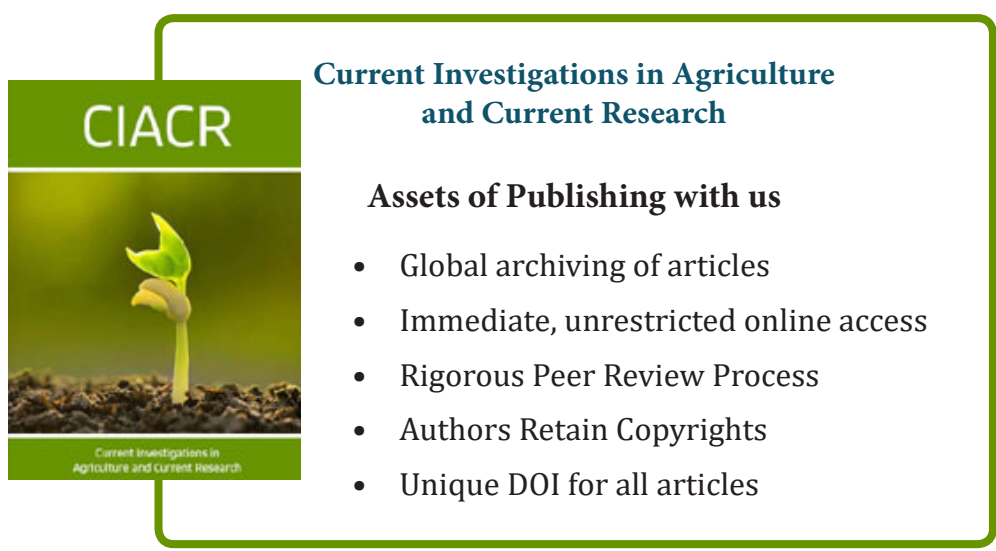

